\title{
ІСТОРІЯ РОЗВИТКУ СИСТЕМИ ВИЩОЇ ОСВІТИ НОВОЇ ЗЕЛАНДІЇ
}

\author{
Пилаєва Т. В. \\ кандидат педагогічних наук, доцент, \\ доиент кафедри педагогіки, іноземної філології та перекладу \\ Харківський національний економічний університет імені Семена Кузнеия \\ пр. Науки, 9-А, Харків, Украӥна \\ orcid.org/0000-0002-7897-5428 \\ tvpilasha@gmail.com
}

\begin{abstract}
Ключові слова:
університетська освіта, заснування університетів, реформи сектору вищиої освіти, освітні заклади "Wanaga Maori".
\end{abstract}

У статті розглянуто проблему виникнення, становлення та розвитку вищої освіти Нової Зеландії. Метою статті є з'ясування фактів та обставин зародження, розвитку та реформування університетської освіти Нової Зеландії. У статті встановлено, що першим університетом Нової Зеландії став університет Отаго у 1869 році. Важливим етапом розвитку вищої освіти було створення Федерального університету Нової Зеландії, який став органом, що проводив оцінювання та здійснював присвоєння наукових ступенів для всіх університетів Нової Зеландії до 1961 року. До початку Першої світової війни в країні було створено п’ять університетів з восьми нині існуючих. 3'ясовано, що Нова Зеландія була однією з перших країн, що надавали можливість отримання вищої освіти жінкам. Встановлено, що наукові дослідження в університетах стали активно проводитися тільки після Другої світової війни. Звернено увагу, що зміна переконань щодо ролі вищої освіти як для особистості, так і для суспільства призвела до двох значущих фаз реформ, які відбулись після виборів четвертого лейбористського уряду в 1984. Значну увагу приділено реформам лейбористського уряду, які призвели до оновлення системи освіти. 3'ясовано, що основними рушійними силами реформи вищої освіти стали невдоволення високим рівнем безробіття внаслідок перебудови економіки. Розглянута роль Університетського комітету 3 надання грантів. Увага приділена роботі та функціонуванню Комітету 3 державного фінансування університетської освіти. Стаття розглядає існування унікальних освітніх установ “Wanaga Maori”, які були засновані як заклади вищої освіти, але втратили статус університету. Встановлено, що на початку XXI століття в Новій Зеландії велика увага приділяється альтернативним формам вищої освіти, пошуку шляхів допомоги студентам у навчанні після отримання обов'язкової освіти та можливостей переміщення студентів між різними гілками системи вищої освіти. 3'ясовано, що третина студентів $€$ іноземцями. Зроблено висновок про те, що протягом свого існування сектор вищої освіти Нової Зеландії пройшов складний шлях, на розвиток якого великий вплив мала низка багатьох зовнішніх сил, таких як політичний розвиток країни, мінливі вимоги студентів, бізнесу та промисловості. 


\title{
HISTORY OF THE DEVELOPMENT OF THE HIGHER EDUCATION SYSTEM OF NEW ZEALAND
}

\author{
Pylaieva T. V. \\ Candidate of Pedagogical Sciences, Associate Professor, \\ Associate Professor at the Department of Pedagogy, Foreign Philology and Translation \\ Simon Kuznets Kharkiv National University of Economics \\ Nauki ave., 9-A, Kharkiv, Ukraine \\ orcid.org/0000-0002-7897-5428 \\ tvpilasha@gmail.com
}

\begin{abstract}
Key words: university education, universities foundation, reforms of the higher education sector, educational institutions "Wanaga Maori".
\end{abstract}

The article deals with the problem of foundation, formation and development of higher education in New Zealand. The purpose of the article is to clarify the facts and circumstances of the origin, development and reforms of university sector in New Zealand. The article states that the first university in New Zealand was the University of Otago, which was founded in 1869. An important stage in the development of higher education was the establishment of the Federal University of New Zealand, which became the only body to evaluate and award degrees for all universities in New Zealand until 1961. Before the First World War, five of the eight existing universities were established in the country. New Zealand is known to be one of the first countries to provide higher education to women. The article points out that scientific research at universities began to be actively conducted only after the Second World War. It is noted that changing beliefs about the role of higher education for both the individual and society have led to two significant phases of reform following the election of the fourth Labour government in 1984. Much attention has been paid to Labour government reforms that have renewed the education system. The article states that the main drivers of higher education reform were dissatisfaction with high unemployment due to economic restructuring. The role of the University Grants Committee is considered. The New Zealand Qualifications Authority is responsible for quality assuring all courses and tertiary education organisations other than universities. The article examines the existence of unique educational institutions "Wanaga Maori", which were founded as institutions of higher education, but lost the status of universities. It is stated that in the early twenty-first century in New Zealand, much attention is paid to alternative forms of higher education, to finding the ways to help students learn after graduation and opportunities to move students between different branches of the higher education system. The article points out that a third of students are foreigners. It is concluded that during its existence, the New Zealand higher education sector has come a long way, which has been greatly influenced by a number of external forces, such as the country's political development, changing demands of students, business and industry.
Постановка проблеми. У період входження України до глобальної освітньої системи важливим $є$ пошук шляхів удосконалення системи університетської освіти. На нашу думку, зразком університетської освіти можуть слугувати університети Великобританії та країн Британської Співдружності, які очолюють світові рейтинги. Всі університети Нової Зеландії входять у престижний рейтинг QS World University Rankings. Система вищої освіти складається 3 уні- верситетів, політехнічних інститутів, педагогічних коледжів, спеціалізованих Маорі інститутів і приватних навчальних закладів. На нашу думку, цікавим $\epsilon$ вивчення досвіду організації вищої освіти у Новій Зеландії з низки причин: 1) вища школа країни є привабливою для іноземних громадян регіону та світу завдяки наполегливій роботі уряду країни; 2) Нова Зеландія є членом Організації економічного співробітництва і розвитку, створеної в 1961 р. на базі Європейської організації 
співробітництва, з метою координації допомоги США та Канади в рамках плану Маршалла під час відбудови Європи після Другої світової війни, таким чином Нова Зеландія запроваджує на своїх теренах кращі світові стандарти освіти; 3) Нова Зеландія є суспільством, яке поєднує у собі представників різних етносоціальних спільнот і $€$ мультикультуральними суперетносами, які утворюють єдину спільноту.

Вища освіта Нової Зеландії фактично не досліджувалася як в Україні, так і на всьому пострадянському просторі. Окремі аспекти освітньої системи Нової Зеландії розглядаються в працях вітчизняних науковців (В. Ставцева, Ж. Таланова, Д. Швець, К. Эйхбаум) та зарубіжних авторів (M. Clarke, L. Flekton, J. Poskitt, K. Taylor). Але історія розвитку вищої освіти Нової Зеландії залишається невивченою в Україні, тому вважаємо цікавим дослідити розвиток вищої освіти країни від самого початку її заснування.

Мета статті - розглянути зародження, розвиток та реформування університетської освіти Нової Зеландії.

Виклад основного матеріалу. 3 кінця XIX століття до середини XX століття існували два основні напрями здобуття освіти після закінчення школи: академічний та неакадемічний. У перші роки розвитку сектору вищої освіти Нової Зеландії дебати йшли навколо структури та співвідношення сил між розформованим натепер Університетом Нової Зеландії та його дочірніми «коледжами». Спираючись на британську модель, початкова система академічної вищої освіти в Новій Зеландії була в основному орієнтована на чоловіків. Неакадемічні форми вищої освіти, такі як політехнічні освітні заклади та технічні коледжі, почали створюватися наприкінці XIX століття та були спрямовані на задоволення освітніх проблем робочого класу. На початку XX століття технічна освіта ставала все більш професійною і необхідною для людей, які прагнути займатися торгівлею.

Першим університетом Нової Зеландії став університет Отаго, заснований у 1869 році постановою ради провінції Отаго. Новому університету було надано 100000 десятин пастирської землі та дозволено надавати ступінь у галузі мистецтв, медицини, права та музики.

Університет відкрився в липні 1871 р., у його штаті було усього три професори: один викладав класику та англійську мову та літературу, інший відповідав за математику та природничу філософію, а третій займався ментальною та моральною філософією та політичною економією. Наступного року штат було розширено професором природничих наук. У 1872 р. навчальна програма була розширена та створені нові лекційні курси: лекції з права розпочалися в 1873 р., а курс медицини було запропоновано у 1875 р. Лекції з гірничої справи читалися з 1872 р., а в 1878 р. була створена школа 3 гірсько-рудних наук. Пізніше в 1907 р. було засновано школу стоматології та у 1911 р. школу домашніх наук (пізніше споживчих та прикладних наук). Викладання предметів бухгалтерського обліку та торгівлі розпочалося у 1912 р. У роки між двома світовими війнами було створено різні нові кафедри та лекційні курси, а в 1946 р. розпочалося викладання на богословському факультеті. Школа фізичного виховання була відкрита в 1947 p. [11].

Федеральний університет Нової Зеландії, який було засновано статутом у 1870 р., став органом, що проводив оцінювання та здійснював присвоєння наукових ступенів для всіх університетів Нової Зеландії до 1961 року. Слід зазначити, що виняткове право присвоєння наукових ступенів залишалось у федерального університету Нової Зеландії близько 90 років, до 1961 р., коли університет Отаго отримав право присвоєння наукових ступенів. На момент створення федерального університету Нової Зеландії існував лише один університет - Університет Отаго. Коли нові освітні установи були створені в Окленді, Кентербері та Веллінгтоні, вони стали складовими коледжами університету; університету Отаго було дозволено зберегти слово «університет» у своїй назві, оскільки його заснування передувало створенню університету Нової Зеландії. Цей перший національний університет був відносно невеликим протягом усього свого існування 3 невеликою кількістю персоналу. В останній рік свого існування (1961) його бюджет на зарплату становив лише 19000 фунтів стерлінгів, тоді як професор заробляв 2000 фунтів, а викладач 1000 фунтів. На відміну від більшості навчальних закладів, у назві яких $\epsilon$ слово «університет», в Університеті Нової Зеландії не було студентів, яким би викладали, та викладачів-науковців, які б викладали. Хоча віцеканцлер університету був академіком, він працював неповний робочий день; один із найдовших службовців університету, сер Томас Хантер, був також професором філософії в університетському коледжі Вікторії.

Окрім того, що він був органом, що проводить іспити та присудження ступенів для всіх університетських коледжів Нової Зеландії, університет Нової Зеландії також відповідав за затвердження кваліфікацій та, що, мабуть, найголовніше, за проведення іспитів та оцінювання робіт. Університетська громада XIX ст. була невеликою і відносно недосвідченою; багато професорів бачили себе виключно викладачами і чинили опір ідеї бути також екзаменаторами. 3 цих причин та для того, щоб новозеландські стандарти освіти були 
на одному рівні зі стандартами Сполученого Королівства, роботи на перевірку відправлялися у Великобританію, таким чином від часу складання іспиту до отримання результатів проходило багато місяців. Ця практика тривала до Другої світової війни, коли виникало багато проблем 3 відправленням паперів у зону бойових дій.

Хоча лише університет Отаго міг претендувати на повний університетський статус, коледжі в Окленді, Кентербері і Веллінгтоні періодично намагалися отримати його, зазначимо, що перша спроба була зроблена ще у 1918 р. Королівська комісія, яка працювала у 1925 р., розглядала можливість зробити Окленд повноцінним університетом. Згідно з постановою цієї комісії Кентербері i Веллінгтон залишилися коледжами в складі Університету Нової Зеландії. Згодом, через п'ять років було розглянуто інший план, згідно з яким планувалось скасувати університет Нової Зеландії і замінити його двома незалежними університетами. Незважаючи на періодичні дискусії протягом наступних кількох років, питання було вирішене лише за допомогою звіту 1959 р., підготовленого професором (згодом сером) Девідом Хьюзом Паррі, колишнім віцеканцлером Лондонського університету [12].

Звіт Хьюза Паррі рекомендував скасувати Університет Нової Зеландії з метою створення чотирьох самостійних університетів. У звіті містилась пропозиція щодо створення та введення в дію центрального національного органу до моменту ліквідації федерального університету для забезпечення задоволення національних потреб. На цей орган, університетський комітет з надання грантів (UGC), мало бути покладено фінансову, а також академічну відповідальність за університети. Для забезпечення плавного переходу він повинен був виникнути 1 січня 1961 р., за рік до того, як університет мав бути ліквідований.

Хоча у звіті X. Паррі не було рекомендацій щодо створення комітету віцеканцлерів, у ньому містилася пропозиція керівникам навчальних закладів регулярно збиратися для обміну інформацією, а Закон про створення університетського комітету з надання грантів (УКНГ) також створив Комітет віцеканцлерів університетів Нової Зеландії (КВКУНЗ). Як і у разі з УКНГ, він офіційно розпочав роботу за рік до розформування федерального університету Нової Зеландії та повністю отримав усі повноваження 1 січня $1962 \mathrm{p}$.

Університетський комітет 3 надання грантів мав вісім членів (усі призначені урядом), голову, трьох неспеціалістів та трьох науковців 3 (тоді чотирьох) університетів. Відповідно до Закону УКНГ мав такі функції та повноваження: 1) публікувати інформацію про університетську освіту та дослідження; 2) перевіряти потреби
Нової Зеландії в університетських дослідженнях; 3) досліджувати фінансові потреби університетів; 4) планувати університетські наукові розробки; 5) виділяти університетам кошти державних грантів; 6) забезпечувати підтримку ради університету зі вступу, комітету з навчальних програм, комітету 3 досліджень, комітету проректорів та ради юридичної освіти [7].

Рада університету зі вступу, хоча і не була підкомітетом УКНГ, мала свого голову та п'ятьох 3 десяти членів, призначених УКНГ. Рада університету зі вступу встановлювала та збирала плату за вступний іспит до університету та була важливим джерелом доходу для існування УКНГ. Протягом існування УКНГ плата за вступні іспити становила близько 75\% усіх доходів УКНГ, хоча ці значні витрати йшли на канцтовари та поштові послуги.

Наприкінці існування університету Нової Зеландії в ньому було створено Комітет з навчальних програм 3 метою забезпечення рівноцінності стандартів курсів, що різнилися за змістом та вивчалися в окремих освітніх установах (коледжах), але пропонувались як ступені університету Нової Зеландії. В межах роботи УКНГ робота Комітету була розширена, зважаючи на необхідність раціонального використання ресурсів, ринкову потребу в нових курсах та їх академічне обгрунтування.

Невелика кількість наукових досліджень в університетах проводилась до Другої світової війни. У деяких університетах дослідження розглядали як відволікання від того, що, на їхню думку, було основною діяльністю університетів - викладання. Зазначимо, що один голова ради коледжу навіть заявив: «Якщо професор має час на дослідження, це свідчить про те, що він не виконує свою роботу належним чином». Після війни це ставлення змінилося, і дослідження стали одними 3 найважливіших напрямів роботи університетів [7].

У 1946 році голова освітньої галузі (директор освіти) надав університету Нової Зеландії 10000 фунтів стерлінгів на університетські дослідження. Згодом у країні був організований Комітет післядипломних стипендій та грантів з бюджетом у 100000 фунтів стерлінгів. Цей комітет складався з голови УКНГ, генерального директора Департаменту наукових та промислових досліджень та п'яти викладачів університетів, який згодом був розширений до семи, коли Мессі та Ваїкато стали університетами. Комітет надав гранти всім підрозділам університетів, за винятком медичних та стоматологічних шкіл, які мали доступ до набагато більших сум, які розподілялись Радою 3 медичних досліджень (попередницею сучасної Ради $з$ питань охорони здоров’я). 
Жінки мали змогу відвідувати університет 3 моменту відкриття Університету Отаго в $1871 \mathrm{p}$. [7]. Інші коледжі дотримувались цієї тенденції; проте права на здобуття наукових ступенів у жінок не було до 1874 р. Першою жінкою, яка отримала бакалаврську освіту, була Кейт Еджер з Кентерберійського університету в 1877 р., тоді як Емілі Сідеберг та Етел Бенджамін з Університету Отаго стали першими жінками-випускниками Нової Зеландії у галузях медицини та права у 1896 та 1897 роках відповідно. До 1900 року в усіх чотирьох коледжах навчалося 805 студентів, 3 них 305 (37,8\%) були жінками.

1 січня 1962 р. Університет Нової Зеландії був розформований, у результаті чого було створено чотири незалежні університети та два асоційовані сільськогосподарські коледжі: Університет Отаго, Університет Кентербері, Університет Оукленду, Університет Вікторії у Веллінгтоні, Кентерберійський сільськогосподарський коледж та сільськогосподарський коледж Мессі.

1 січня 1964 р. у країні було створено два нові університети - Університет Ваїкато та Університет Мессі. Університет Ваїкато започатковувався для задоволення освітніх потреб регіону навколо м. Гамільтона, тепер четвертого за розміром міста Нової Зеландії. Університет Мессі в місті Палмерстон-Норт спочатку був створений як Новозеландський сільськогосподарський коледж у 1926 р. (перейменований у Сільськогосподарський коледж Мессі в 1927 р.) [11;12].

Реформи Лейбористського уряду 1984-90 pр. призвели до значного оновлення системи освіти. Закон про освіту 1989 р. скасував УКНГ та Департамент освіти, а також створив Міністерство освіти та Кваліфікаційний орган Нової Зеландії. Хоча всі заклади вищої освіти отримали більшу автономію, контроль за фінансуванням (що надається пропорційно до кількості студентів денної форми навчання) було передано міністерству.

Низка функцій УКНГ була передана до ради віцеканцлерів Нової Зеландії, що отримала додаткові ресурси від університетів для виконання своїх нових обов'язків.

У 1990 р. було створено університет Лінкольна (поблизу Крайстчерча на Південному острові), який пройшов складний шлях від школи до університету. Школа сільського господарства була створена в Лінкольні в 1878 р., а в 1896 р. іiі було перейменовано на Кентерберійський сільськогосподарський коледж та було надано право присудження освітніх ступенів за посередництвом федерального університету Нової Зеландії. Кентерберійський сільськогосподарський коледж було перейменовано на коледж Лінкольна в 1961 р., який став складовим коледжем Кентерберійського університету, поки згодом не отримав статус повноцінного та самоврядного університету.

Останній університет, заснований у Новій Зеландії, - Оклендський технологічний університет був відкритий на зламі століть у 2000 році. Як університети Мессі та Лінкольна, він має давню історію. Він був започаткований як Оклендська технічна школа в 1895 р. У 1960 р. функції середньої школи та функції закладу вищої освіти було розділено і створено Оклендський технічний інститут. Назву інституту було змінено на Оклендський технологічний інститут у 1989 р., який і став Оклендським технологічним університетом 1 січня 2000 р. Нині Оклендський університет пропонує навчання як сучасних професій (креативні технології, мистецтво, дизайн тощо), так і традиційних спеціальностей.

Слід зауважити, що не кожен заклад вищої освіти Нової Зеландії має статус університету [8]. Тому згідно із «Законом про освіту», прийнятим у 1989 р., університетом вважається заклад, що має відповідний науково-педагогічний потенціал, проводить наукову діяльність завдяки навчанню студентів, які бажають отримати глибокі знання, здійснює поглиблене навчання, має визнання у суспільстві, рівень освіти ЗВО повинен відповідати міжнародним вимогам 3 наукових досліджень та навчання. Крім цього, університет як заклад вищої освіти повинен формувати не лише базові професійні вміння, але й високу майстерність, уміння аналізувати, мислити, спілкуватися, адаптуватися до інноваційних технологій. Також у «Законі про освіту» зазначено, що університети зобов' язані надавати освіту та робити свій внесок у соціальний, економічний i фізичний добробут країни. Всі наведені вище університети фінансуються державою і $є$ партнерами у сферах навчання та наукових досліджень. Вони забезпечують вищу освіту (tertiary education) приблизно 110 тис. студентів та роботу 20 тис. викладачів [2].

У Новій Зеландії $є$ унікальні освітні установи "Wanaga Maori", що засновані як заклади вищої освіти наприкінці XX ст. Вони пропонують поглиблене навчання та науково-дослідницькі програми, в яких традиції та звичаї культури корінного населення Нової Зеландії маорі $\epsilon$ головною складовою частиною підготовки. Щороку група викладачів і студентів «занурюється» у середовище мови маорі. Метою діяльності таких закладів освіти є збільшення кількості людей, які вільно володіють мовою маорі, та збереження ідентичності маорі, а також підсилення вагомості навчальних методів маорі. Предмети та спеціальності у цих закладах освіти досить специфічні: збирання та виготовлення льону; плетіння; виготовлення тканини ручної роботи чи гобелену стилем "Wanaga”; різьблення по 
дереву. Найяскравішим прикладом навчального закладу такого типу можна вважати "Te Wanaga o Aoteoroa", мовою маорі ця назва означає «Університет Нової Зеландії». Останнім часом він став найбільшим державним закладом освіти, який пропонує навчальні програми в усіх університетських кампусах. У 1984 р. "Te Wanaga o Aoteoroa" був заснований як приватний навчальний заклад «Центр мистецтв». Згодом, за десять років він отримав статус закладу вищої освіти. У 2000 р. 3 державного бюджету виділили 239 млн доларів на його розвиток. Згідно зі статистикою, на початку XXI століття в університеті навчалося 22 тис. студентів стаціонару та нараховувалося 13 університетських містечок у північній частині Нової Зеландії. Загальна кількість студентів заочної форми навчання у цьому освітньому закладі перевищила 60 тис. Декілька років “Tе Wanaga о Aoteoroa" присуджував ступені бакалавра і мав дозвіл надавати ступені магістра та доктора наук завдяки партнерству 3 Кертінським університетом в Австралії. Навчальний заклад почав стрімко розвивати наукові дослідження, але під значним політичним тиском перестав «позиціонувати» себе як університет у 2005 р. Комісія вищої освіти Нової Зеландії (Tertiary Education Commission of New Zealand) дійшла висновку, що систематичні міжнародні порівняння результатів наукових досліджень не мали особливої значущості для розвитку університетів держави. Незважаючи на те, що цей навчальний заклад є досить молодим, він знаний у світі завдяки успішним комп'ютерним програмам (програма віртуального навчального центру); навчанню мови маорі; наочним мистецтвам, включаючи плетіння та різьблення по дереву [2, с. 115].

1961 р. було створено Комітет проректорів Нової Зеландії (NZVCC) відповідно до Закону про освіту 1961 р., який було перейменовано на «Університети Нової Зеландії - Те Pōkai Tara».

Зміна переконань щодо ролі вищої освіти як для окремої особистості, так і для суспільства загалом призвела до двох значних фаз реформи, що відбулися після обрання четвертого лейбористського уряду в 1984 році. Основні рушійники реформи вищої освіти походять від зростаючого переконання у тому, що постачальники вищої освіти не реагують на зміни. Незадоволення було ще більш нагальним через високий рівень безробіття внаслідок перебудови економіки; стало ще більш очевидним, що для забезпечення фінансової стабільності людям необхідна вища освіта [7]. У 1970-х рр. зростав як попит на навички, так і усвідомлення того, що вимоги до навичок «ймовірно будуть розвиватися протягом трудового життя людини». Відповідно, це призвело до збільшення цінності вищої освіти в очах новозеландців.
Перший етап реформи був реалізований у вигляді єдиної об'ємної системи фінансування всіх секторів вищої освіти. Реформа була зосереджена на збільшенні самостійності вищих навчальних закладів, збільшенні фінансування для заохочення участі та полегшення системи переходу студентів між різними частинами системи освіти. Схема студентської позики, яка була створена у 1992 році, також була розроблена для заохочення новозеландців до отримання вищої освіти. У результаті впровадження системи «легкої руки» спостерігалося зростання попиту на отримання вищої освіти серед груп, які традиційно не брали участь у секторі вищої освіти, наприклад, населення маорі та старші вікові групи. Однак у результаті урядової реформи сектор вищої освіти зазнав перевищення бажаючих навчатися, що створювало проблеми 3 державним фінансуванням [7].

П'ятий уряд лейбористів розпочав другий етап реформ після 1984 р. У 1984 р. представники Державного казначейства в документі «Економічний менеджмент» окреслили новообраному уряду вимоги щодо економічних реформ. Вони звернули увагу уряду на вільний економічний ринок, на необхідність чіткого визначення цілей його розвитку та способів їх досягнення. Казначейство пропонувало ефективніше використовувати ринкові процеси в наданні освітніх послуг, його представники наполягали на тому, що вища освіта $\epsilon$ більш приватним, аніж державним пріоритетом, i назвали університетську ланку одним із чинників неефективності економіки країни. Вони підкреслили, що слабкий рівень їі функціонування негативно впливає на роботу ринку праці зокрема і на розвиток економіки загалом [5, с. $65 ; 10$, с. 23].

У 1986 р. робочою групою під керівництвом Д. Біті (D. Beattie) була підготовлена доповідь «Ключ до процвітання: наука і технології». В доповіді стверджувалось, що Нова Зеландія вкладає відносно малі кошти від ВВП в університетські наукові дослідження порівняно 3 іншими країнами, що входили до складу Організації економічного співробітництва і розвитку. Особливу увагу було приділено важливості проведення наукових розвідок для майбутнього країни. Д. Біті підкреслив, що неможливо точно знати наперед, які галузі науки будуть на першому місці в майбутньому. Тому факультети університетів не повинні концентрувати увагу лише на практичних проблемах, а насамперед прогнозувати важливі перспективні галузі економіки і займатися відповідними науковими дослідженнями [5, с. 118; 3] .

Урядом лібералів було запропоновано перераховувати кошти із загальної суми державного фінансування університетів на рахунок дослідницьких лабораторій, і до 1994 р. відбулось збіль- 
шення витрат на проведення наукових досліджень 390 млн новозеландських доларів до 160 млн [10, с. 25]. Зміни та реформи, які розпочалися у 1984 р., пов'язувалися із політикою «нового права» (New Right). Ïї характерними рисами стали зменшення ролі уряду в управлінні університетами та надання переваг функціонуванню ринкових принципів у діяльності ВНЗ [3].

У період реформи 1984-1990 рр. три адміністративні органи брали участь в управлінні системою вищої освіти: Комітет $з$ державного фінансування університетської освіти, Міністерство освіти і Державне казначейство, відмітною рисою яких був бюрократичний стиль адміністрування. Це шкодило університетам, оскільки Міністерство освіти і Державне казначейство намагалися контролювати заклади вищої освіти, використовуючи фактори додаткових витрат і незадовільного ставлення викладачів. Урядовці прагнули зменшити фінансування університетів до рівня політехнічних інститутів, які мали статус елітних, незважаючи навіть на старомодні ідеології, відсутність конкуренції та задоволення потреб ринку праці [6, с. 181; 9].

У країні було створено Комітет $з$ державного фінансування університетської освіти, до складу якого входили по одному представнику від кожного університету та чотири особи, сфера діяльності яких не була пов'язана з освітою. Головним обов'язком Комітету з державного фінансування університетської освіти було управління всіма державними коштами, які уряд виділяв на розвиток університетів. Це був орган, що відповідає за розвиток та ефективну діяльність університетської освіти. Робота комітету була ефективною, оскільки він співпрацював як з урядом країни, так i 3 університетами, будучи фінансово незалежним від виконавчої влади. Пріоритетом роботи комітету було прагнення уникання бюрократизму. КДФУО постійно утримував ініціативу щодо питань фінансування університетів. Сприйняття закладами освіти комітету як головного адміністративного органу позитивно впливало на його ефективну роботу, оскільки у університетів 3'явилась можливість передавати свої зауваження та пропозиції для уряду через комітет. Це допомагало університетам уникати політичного контролю з боку держави [1].

У результаті політичного тиску та економічної кризи 80-х рр. ХX ст. Комітет з державного фінансування університетської освіти почав втрачати свої позиції. Г. Хок запропонував передати повноваження цього адміністративного органу Міністерству освіти, яке повинне було стати відповідальним за всю систему освіти у державі, або тільки що створеному Комітету віцеканцлерів Нової Зеландії. Наприкінці 1990 р. Комітет 3 державного фінансування університетської освіти припинив свою діяльність згідно із «Поправкою до закону про освіту». Як зазначали освітяни, після розформування КДФУО відбулася більш жорстка централізація влади та зміцнення повноважень бюрократичного управління [5, с. 135].

Кінець ХX ст. ознаменувався повільним зростанням економіки. Університети отримали можливість урізноманітнити програми післядипломного навчання 3 огляду на потреби всіх сфер життєдіяльності країни. Періодичні видання того часу «Домініон» і «Преса» зазначали, що університетська освіта Нової Зеландії не була ідеальною, але вона розвивалася задля задоволення потреб країни. Тому уряду пропонувалося не руйнувати досягнення минулого для втілення власних ідей для збереження коштів [2].

У 2000-х роках відбулися значні зрушення у пріоритетах фінансування освіти на користь університетів. Ця зміни включали в себе створення матеріальних умов для навчання за рахунок розподілу витрат між урядом та студентами, пільги по кредитах та контроль за встановленням плати за навчання [7]. Друга хвиля реформ також була зосереджена на формуванні національних цілей вищої освіти - уряд намагався керувати системою вищої освіти відповідно до національних пріоритетів держави, одночасно дозволяючи закладам освіти зберігати свою автономію. Протягом XXI століття в країні тривають суперечки щодо відсоткового внеску, який має вносити уряд та студенти в отримання вищої освіти, з урахуванням переваг, які надає освіта як для розвитку особистості, так і для держави загалом.

На початку XXI століття в Новій Зеландії велика увага приділяється альтернативним формам вищої освіти, йдеться про пошук шляхів допомоги студентам у навчанні після отримання обов'язкової освіти та можливостей переміщення студентів між різними гілками системи вищої освіти. Особливу увагу уряд країни приділяє збільшенню студентського контингенту серед вихідців Тихоокеанських островів та народу маорі.

При кожному університеті Нової Зеландії $\epsilon$ розвинена інфраструктура обслуговуючого освітнього управління (educational-corporative servicemanagement), яка включає юридичну службу, медичне обслуговування, службу працевлаштування, управління студентськими гуртожитками. Вони забезпечують супровід студентів у їх переміщеннях між різними суб'єктами соціального простору: роботодавцями, орендодавцями житла, системою соціального страхування та медичного обслуговування. Університети Нової Зеландії пропонують своїм студентам широкий спектр спеціальностей, однак у кожного з них є свої традиційні факультети із науковими мікроелітами, 
науковими школами та академічними авторитетами, що наближає іiї систему управління 3ВО до Великої Британії. Вищі органи управління освітою Нової Зеландії в оцінці діяльності ЗВО керуються селекційною моделлю адаптації університету до зовнішнього середовища [4].

Нині заклади вищої освіти Нової Зеландії частково фінансуються державою, але право на повне або часткове покриття витрат на навчання мають лише місцеві громадяни або постійні жителі. Заклади вищої освіти країни поділено на 4 групи (п'ятизіркові, чотиризіркові, тризіркові та університети-лідери за якістю наукових досліджень) залежно від рейтингу, який дає можливість визначити рівень їх популярності за різними критеріями, такими як: задоволеність студентів рівнем викладання, проведенням наукових досліджень, співвідношення чисельності студентів та викладачів, забезпеченість комп'ютерами та бібліотечним фондом; наявність умов для занять спортом, медичних, юридичних та кар'єрних служб, технічної оснащеності навчального процесу, успішність студентів, відсоток осіб, які отримали наукові ступені, перспективи роботи за спеціальністю [4, с. 132].

Слід зауважити, що отримання вищої освіти в Новій Зеландії $є$ популярним серед іноземних студентів, приблизно третина студентів $є$ іноземцями. Щороку до країни приїжджають 30 тис. абітурієнтів з різних країн світу, що свідчить про сприятливі умови для отримання вищої освіти.
Висновки. Таким чином, засновники вищої освіти Нової Зеландії орієнтувалися на британську модель, оскільки країна була частиною Великої Британії. Протягом свого існування сектор вищої освіти Нової Зеландії пройшов складний шлях, на розвиток якого великий вплив мала низка багатьох зовнішніх сил, таких як політичний розвиток країни, мінливі вимоги студентів, бізнесу та промисловості. Зростання попиту 3 боку населення і бізнесу зробило великий вплив на характер самих університетів, сприяючи їх зростанню та впливаючи на зміст курсів, які вони пропонують. Новозеландська система освіти $€$ близькою до англійської, але набула специфічних рис: 1) вона відрізняється високим рівнем якості державної освіти (різниця між державною та приватною освітою невелика); 2) характерною рисою освіти Нової Зеландії є жорстке державне управління сферою освіти (кожний навчальний заклад регулярно відвідує державна інспекція, результати перевірок університетів можна знайти на вебсайті комітету віцеканцлера; 3) спрощена система вступу до університету відрізняє новозеландську систему освіти від британської. Особливу увагу привертають заклади "Wanaga", які підтримують і розвивають традиції народу маорі (плетіння, збирання льону, виготовлення тканин, різьблення по дереву тощо).

Предметом наступних наукових досліджень може бути детальне вивчення та аналіз функціонування закладів освіти “Wanaga".

\section{ЛІТЕРАТУРА}

1. Ставцева В.Ф. Реорганізація унітарного університету Нової Зеландії на початку 70-х років XX століття. Вісник Житомирського державного університету. Житомир, 2012. Вип. 63. С. 204-208.

2. Ставцева В.Ф. Система освіти Нової Зеландії (загальна характеристика. Науковий вісник кафедри ЮНЕСКО Київського національного лінгвістичного університету. Філологія, педагогіка, психологія. 2010. Вип. 20. С. 109-116.

3. Ставцева В. Трансформаційні процеси 80-х pp. ХХ століття в університетській ланці освіти Нової Зеландіï. URL: https://oldconf.neasmo.org.ua/node/934 (дата звернення: 10.01.21).

4. Швець Д.Є. Концептуалізація моделі управління вищою освітою в Австралії і Новій Зеландії. Вісник НТУУ «КПІ». Політологія. Соціологія. Право : збірник наукових праць. 2011. № 4 (12). С. $131-135$.

5. Butterworth R., Tarling N. A shakeup anyway. Government and the Universities in New Zealand in a Decade of Reform. Auckland University Press. 1994. 268 p.

6. Malcolm W., Tarling N.. Crisis of identity? The mission and management of Universities in New Zealand. Dunmore Publishing Ltd., 2007. 256 p.

7. McLaughlin M. Tertiary Education Policy In New Zealand. URL: https://www.fulbright.org.nz/wp-content/ uploads/2011/12/axford2002_mclaughlin.pdf (дата звернення: 20.12.20).

8. Ministry of Education. URL: http.//www.minedu.govt.nz/ (дата звернення: 28.12.20).

9. Olssen M. The restructuring of tertiary education in New Zealand: governmentality, neo-liberalism, democracy. McGill Journal of Education 2002. Vol. 37(001). P. 57-86.

10. Patterson G. New Zealand Universities under the Fourth Labour Government. An analysis of events affecting the New Zealand university system 1984-1990. Massey University Printery, 1991. 204 p.

11. Short history of New Zealand Universities. URL: https:/www.universitiesnz.ac.nz/about-universitysector/brief-history (дата звернення: 15.12.20).

12. Tearney F. History of education in New Zealand. The McGuinness Institute. Working Paper. 2016. Vol. 3. 57 p. 


\section{REFERENCES}

1. Stavtseva, V.F. (2012). Reorhanizatsiia unitarnoho universytetu Novoi Zelandii na pochatku 70-kh rokiv XX stolittia [Reorganization of the Unitary University of New Zealand in the early 70s of the twentieth century]. Bulletin of Zhytomyr State University. Vol. 63. P. 204-208.

2. Stavtseva, V.F. (2010). Systema osvity Novoi Zelandii (zahalna kharakterystyka) [New Zealand education system (general characteristics)]. Scientific Bulletin of the UNESCO Department of Kyiv National Linguistic University. Philology, Pedagogy, Psychology. Vol. 20. P. 109-116.

3. Stavtseva, V. Transformatsiini protsesy $80-\mathrm{kh}$ rr. XX stolittia v universytetskii lantsi osvity Novoi Zelandii [Transformation processes of the 80 s of the XX century in the university education chain of New Zealand]. URL: https://oldconf.neasmo.org.ua/node/934.

4. Shvets, D.Ye. (2011). Kontseptualizatsiia modeli upravlinnia vyshchoiu osvitoiu v Avstralii i Novii Zelandii [Conceptualization of the higher education management model in Australia and New Zealand]. Bulletin of NTUU "KPI". Politology. Sociology. Law: a collection of scientific papers. No. 4 (12). P. 131-135.

5. Butterworth, R., Tarling, N. (1994). A shakeup anyway. Government and the Universities in New Zealand in a Decade of Reform. Auckland University Press. 268 p.

6. Malcolm, W., Tarling, N. (2007). Crisis of identity? The mission and management of Universities in New Zealand. Dunmore Publishing Ltd. 256 p.

7. McLaughlin M. Tertiary Education Policy In New Zealand. URL: https://www.fulbright.org.nz/wp-content/ uploads/2011/12/axford2002_mclaughlin.pdf.

8. Ministry of Education. URL: http.//www.minedu.govt.nz/.

9. Olssen, M. (2002). The restructuring of tertiary education in New Zealand: governmentality, neo-liberalism, democracy. McGill Journal of Education. Vol. 37(001). P. 57-86.

10. Patterson, G. (1991). New Zealand Universities under the Fourth Labour Government. An analysis of events affecting the New Zealand university system 1984-1990. Massey University Printery, 204 p.

11. Short history of New Zealand Universities. URL: https://www.universitiesnz.ac.nz/about-universitysector/brief-history.

12. Tearney, F. (2016). History of education in New Zealand. The McGuinness Institute. Working Paper. Vol. $3.57 \mathrm{p}$. 